\title{
Simulasi Pembentukan Kurva Isodosis Berkas Foton 6 MV untuk Teknik Radioterapi VMAT dengan Menggunakan EGSnrc
}

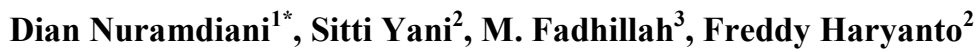 \\ ${ }^{1}$ Program Studi Radiologi, Politeknik Al Islam Bandung, Jl. Cisaranten Kulon \\ 120 Bandung 40293, Indonesia \\ ${ }^{2}$ Laboratorium Fisika Nuklir dan Biofisika, Institut Teknologi Bandung, Jl. \\ Ganesha 10 Bandung 40132, Indonesia \\ ${ }^{3}$ Tan Tock Seng Hospital, Singapura
}

*Penulis Penanggungjawab E-mail : : nenkdee@gmail.com

\begin{abstract}
ABSTRAK
Radioterapi merupakan salah satu modalitas utama dalam pengobatan kanker. VMAT (Volumetric Modulated Arc Therapy) merupakan salah satu teknik radioterapi yang memberikan seluruh fraksi dosis secara kontinyu pada saat gantry terus menerus berotasi dengan mengatur kecepatan rotasi gantry, bentuk penampang berkas (MLC leaf position), dan fraksi dosis yang diberikan. Dalam penelitian ini dilakukan simulasi Monte Carlo VMAT dengan menggunakan EGSnrc code system untuk mengetahui distribusi dosis radiasi berkas foton 6 MV pada kasus kanker paru dengan data parameter berasal dari rtplan. Phantom yang digunakan berasal dari data CT scan thorax yang dibaca dengan ctcreate. Simulasi dilakukan dengan membagi jumlah control point VMAT ke dalam 38 kali simulasi dengan setiap simulasi terdiri dari 3 buah control point. Sebagai perbandingan dilakukan pula simulasi VMAT dengan seluruh control point sekaligus. Hasil menunjukkan bahwa distribusi dosis yang terbentuk dari kedua simulasi cenderung memiliki pola kurva isodosis yang hampir serupa, namun perbandingan jumlah history partikel yang digunakan untuk membentuk kurva isodosis yang sama antara kedua simulasi belum dapat diketahui secara pasti.
\end{abstract}

Kata Kunci : Radioterapi; VMAT; Monte Carlo; Titik kontrol; Kurva Isodosis 


\begin{abstract}
Radiotherapy is one of major modalities in cancer treatment. VMAT (Volumetric Modulated Arc Therapy) is a radiotherapy technique, which provides a continuous full dose radiation as the gantry rotates (dynamic beam delivery) that manages gantry rotation speed, beam cross-sectional shape arranged by MLC leaf position, and fraction of the given dose simultaneously as the treatments take place. The aim of this study was to conduct Monte Carlo VMAT simulation using EGSnrc code system to determine dose distribution of radiation in lung cancer using parameters data deriving from the rtplan. The phantom used comes from data CT scans of thorax, which was then read by ctcreate. Simulation was done by dividing the number of control points of VMAT into 38 simulations in which each simulation consists of three pieces of control point. As a comparison, a VMAT simulation with all of control points was done simultaneously at a time. The results suggest that the dose distributions formed from the sum of data from all simulations with 3 control points tend to have a similar pattern to the dose distribution form of simulations involving all control points, but the comparison of the number of particles history used to form the same isodose curve between the two simulations can not be known for certain.
\end{abstract}

Keywords : Radioteraphy; VMAT; Monte Carlo; Control point; Isodose Curve

\section{Pendahuluan}

Radioterapi adalah salah satu metode pengobatan kanker dengan memanfaatkan berkas radiasi sinar pengion berenergi tinggi. Radioterapi digunakan oleh hampir 70\% dari penderita kanker, baik digunakan sebagai terapi tunggal maupun terapi yang dikombinasikan dengan kemoterapi dan atau operasi pembedahan. Tujuan utama dari radioterapi adalah untuk mengontrol tumor dengan memberikan dosis maksimal pada sel-sel kanker, dan memberikan dosis minimal pada sel-sel sehat di sekitar kanker.

Berbagai teknik radioterapi terus dikembangkan untuk mencapai sistem pengobatan yang lebih akurat dalam meningkatkan kontrol tumor, salah satunya adalah teknik Volumetric Modulated Arc Therapy atau VMAT delivery technique. VMAT merupakan salah satu jenis teknik radioterapi yang menghantarkan seluruh fraksi dosis secara kontinyu pada saat gantry terus menerus berotasi (dynamic beam delivery) dengan mengatur tiga variabel utama yang berubah secara simultan saat treatment berlangsung, yaitu kecepatan rotasi 
gantry, bentuk penampang berkas yang diatur oleh pergerakan Multi leaf collimator (MLC), dan fraksi dosis yang diberikan.

Selain pemilihan teknik radioterapi yang tepat, hal lain yang perlu dilakukan dalam perencanaan perlakuan pengobatan adalah perhitungan dosis radiasi. Tujuannya adalah untuk memastikan dosis yang diberikan tepat sasaran, sehingga dapat memaksimalkan dosis pada sel kanker, dan aman untuk sel-sel sehat di sekitarnya.

Salah satu metode yang sering digunakan dalam perhitungan dosis adalah melalui simulasi komputasi Monte Carlo (MC). Metode ini memodelkan seluruh proses mikroskopik dengan mengikuti trayektori dari setiap partikel yang disimulasikan [1]. Setiap interaksi fisis dari partikel dengan materi akan dihitung dengan menggunakan metode sampling dari suatu fungsi distribusi probabilistik, sehingga banyak penelitian yang menyebutkan bahwa Monte Carlo merupakan metode paling akurat dalam menghitung distribusi dosis, khususnya pada jaringan inhomogen ketika efek transport elektron tidak dapat dihitung secara tepat dengan metode konvensional menggunakan algoritma secara deterministik [2].

Salah satu software yang paling populer digunakan dalam Treatment Planning System (TPS) radioterapi adalah
EGSnrc. Electron Gamma Shower (EGS) merupakan suatu perangkat lunak dengan algoritma Monte Carlo yang digunakan untuk mensimulasikan perjalanan foton dan elektron/positron berdasarkan interaksi fisis yang terjadi secara acak [3]. Foton yang dapat disimulasikan memiliki rentang energi dari energi $1 \mathrm{keV}$ sampai ratusan $\mathrm{GeV}$, dan elektron yang dapat disimulasikan memiliki rentang energi dari puluhan keV hingga ratusan $\mathrm{GeV}$.

Dalam penelitian ini dilakukan simulasi komputasi teknik VMAT dengan menggunakan EGSnrc untuk mengetahui kurva isodosis yang terbentuk pada kasus kanker paru. Phantom yang digunakan berasal dari data CT scan, dan energi foton yang digunakan sebesar $6 \mathrm{MV}$. Pemilihan teknik VMAT dalam simulasi ini berdasarkan dari beberapa keuntungan bila dibandingkan dengan teknik radioterapi lain seperti 3DCRT dan IMAT. Diantaranya adalah mampu meningkatkan efisiensi monitor unit (MU) yang diberikan pada pasien, artinya MU yang diberikan selama perlakuan menjadi lebih rendah [4][5][6]. Peningkatan efisiensi MU ini menyebabkan penambahan waktu pemakaian mesin linac dan mengurangi kebocoran dosis ataupun dosis yang terhambur, serta mengurangi terjadinya resiko dosis berlebih pada pasien. Selain itu, keuntungan lainnya adalah meningkatkan efisiensi waktu perlakuan. 


\section{Bahan dan Metode Penelitian}

Simulasi VMAT MC dilakukan dengan menggunakan software EGSnrc, yang di dalamnya terdiri dari beberapa program, diantaranya adalah BEAMnrc dan DOSXYZnrc. BEAMnrc digunakan untuk memodelkan sumber radioterapi khususnya treatment head pada linac, sedangkan DOSXYZnrc dikembangkan untuk mensimulasikan transportasi foton maupun elektron dalam materi dan menghitung distribusi dosis pada phantom yang tersusun dari banyak elemen volume (voxel), dimana setiap voxel dapat memiliki densitas dan material yang bervariasi.

Data parameter yang digunakan dalam simulasi VMAT-MC berasal dari parameter plan (rtplan) untuk kanker paru yang diperoleh dari Tan Tock Seng Hospital, Singapura. Phantom yang digunakan berasal dari data CT scan thorax yang dikonversi ke dalam phantom virtual dengan menggunakan program ctcreate. Sumber berkas berasal dari phase space file dari model head linac yang sudah terkalibrasi dengan energi $6 \mathrm{MV}$.

Pembacaan rtplan dilakukan dengan menggunakan software DICOMan. DICOMan merupakan salah satu piranti lunak yang dapat membantu pembacaan file baik dalam format DICOM maupun non-DICOM, sekaligus dapat memvisualisasikan gambar CT scan. Dari pembacaan data rtplan dengan DICOMan diperoleh informasi mengenai jumlah leaf pada MLC dengan ketebalan masing-masing leaf, serta data setiap posisi dari masingmasing leaf baik untuk bank $A$ dan bank $B$ (setiap pasangan leaf) pada setiap perubahan segmen. Selanjutnya data posisi MLC ini disimpan dalam satu file sequence yang nantinya akan dikompilasi menjadi BEAM shared library untuk mengsinkronisasikan BEAMnrc dan DOSXYZnrc, karena MLC leaf position dalam simulasi VMAT merupakan komponen yang bergerak secara dinamis saat gantry berotasi.

Selain posisi MLC leaf, informasi lainnya yang terdapat pada rtplan adalah koordinat isocentre, sudut rotasi gantry, sudut kolimator, dan MU indeks, yang selanjutnya akan digunakan dalam pengaturan masing-masing control point DOSXYZnrc. Control point inilah yang merupakan titik optimasi pemberian dosis radiasi dengan melakukan pengaturan dari setiap perubahan bukaan MLC serta pemberian MU pada pasien selama gantry berotasi.

Simulasi dilakukan dengan menggunakan 5 buah komputer dengan spesifikasi Intel i5-4670K $3.4 \mathrm{GHz}$, dan Intel $\mathrm{i} 3-2100 \mathrm{~K} 3.1 \mathrm{GHz}$ dengan masingmasing 4 core yang berada di lab. 
Biofisika dan lab. Komputasi ITB. Dalam penelitian ini, simulasi dilakukan dengan membagi titik control point ke dalam beberapa kali simulasi dengan jumlah control point yang digunakan pada setiap simulasi sejumlah 3 buah. Jumlah keseluruhan control point yang diperoleh dari rtplan adalah 114 buah, sehingga simulasi dilakukan sebanyak 38 kali.

Sebagai pembanding distribusi dosis dari simulasi VMAT yang dilakukan beberapa kali dengan membagi jumlah control point, dilakukan pula simulasi VMAT dengan menggunakan seluruh control point sekaligus (tanpa membaginya menjadi beberapa bagian), namun dengan jumlah history partikel yang jauh lebih sedikit dibandingkan dengan jumlah total history yang digunakan dalam simulasi yang dilakukan secara berulang.

\section{Hasil dan Pembahasan}

Dari hasil pembacaan parameter pada rtplan diperoleh informasi bahwa gantry diatur untuk berotasi hanya satu kali putaran (single arc delivery) dari sudut $270^{\circ}$ sampai dengan sudut $179^{\circ}$, dengan arah putaran searah dengan putaran jarum jam (clock wise). Dalam satu kali rotasi gantry, pemberian dosis radiasi dibagi menjadi beberapa segmen yang disebut dengan control point. Jumlah control point sebanyak 114 buah, dengan perbedaan sudut antara dua control point minimal $1,200897^{\circ}$ dan maksimal 2,46874․ Posisi MLC akan selalu berubah selama gantry berotasi sesuai dengan bentuk target yang akan diradiasi. Perubahan posisi MLC ini terjadi sebanyak 114 kali sesuai dengan jumlah control point.

Pembacaan citra CT scan dengan ctcreate bertujuan untuk mengkonversi data citra CT scan menjadi phantom virtual yang berisi informasi data yang dibutuhkan oleh DOSXYZnrc, salah satunya berupa informasi densitas dan material penyusun phantom sebagaimana yang disajikan pada Gambar 1. Dari pembacaan tersebut diketahui pula ukuran

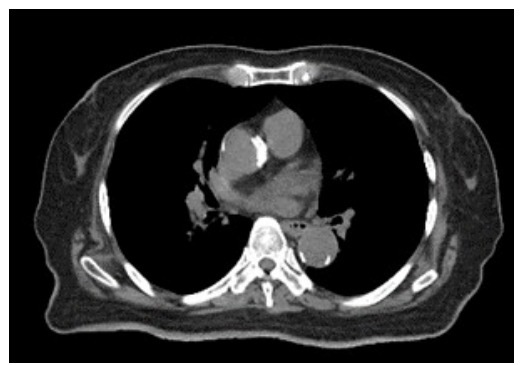

(a)

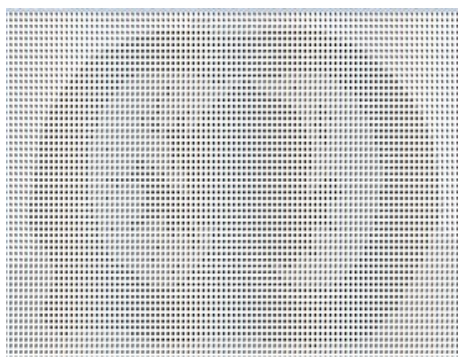

(b)

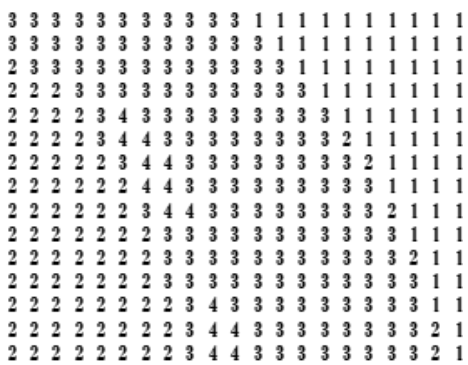

(c)

Gambar 1. (a) Tampilan citra axial phantom CT scan divisualisasikan dengan menggunakan DICOMan.

(b) Potongan axial phantom yang telah diubah dengan menggunakan ctcreate dalam bentuk numerik. (c) Perbesaran potongan axial phantom dalam bentuk numerik. 
Tabel 1. Jumlah dan Ukuran Voxel pada Phantom Thorax

\begin{tabular}{llll}
\hline Sumbu & $\begin{array}{l}\text { Jumlah } \\
\text { Voxel }\end{array}$ & $\begin{array}{l}\text { Ukuran } \\
\text { Voxel }(\mathbf{c m})\end{array}$ & Nilai batas voxel \\
\hline $\mathrm{X}$ & 128 & 0,3708 & $-24,016 \mathrm{~cm}$ sampai $+23,354 \mathrm{~cm}$ \\
$\mathrm{Y}$ & 128 & 0,3708 & $-23,694 \mathrm{~cm}$ sampai $+23,676 \mathrm{~cm}$ \\
$\mathrm{Z}$ & 116 & 0,3 & $-114,7 \mathrm{~cm}$ sampai $+149,2 \mathrm{~cm}$ \\
\hline
\end{tabular}

Sumber: ctcreate

phantom yang selanjutnya dilakukan pengaturan ukuran phantom menjadi ukuran yang lebih kecil (voxel) sebagaimana yang disajikan pada Tabel 1 .

Angka-angka yang terdapat pada potongan phantom virtual ( Gambar 1) dari data CT scan yang sudah dalam bentuk numerik terdiri dari dari angka 1, 2, 3, dan 4, yang masing-masing angka menunjukkan jenis material dan densitas penyusun phantom yang berbeda. Angka 1 menyatakan material udara, angka 2 menyatakan material paru, angka 3 menyatakan material jaringan lunak, dan angka 4 menyatakan material tulang.

Simulasi yang dilakukan pada penelitian ini dilakukan beberapa kali dengan menggunakan jumlah history sebanyak $2 \times 10^{7}$ partikel pada setiap simulasinya. Setiap simulasi yang dilakukan hanya menggunakan jumlah control point sebanyak 3 buah dari 114 buah control point secara keseluruhan, sehingga jumlah pengulangan simulasi adalah sebanyak 38 kali.

Tabel 2 menginformasikan bahwa jumlah history yang disimulasikan dan
Tabel 2. Informasi jumlah partikel yang digunakan dalam simulasi MC VMAT delivery technique dengan DOSXYZnrc

\begin{tabular}{lc}
\hline $\begin{array}{l}\text { Jumlah simulasi yang } \\
\text { dilakukan }\end{array}$ & 38 kali \\
\hline $\begin{array}{l}\text { Jumlah history yang } \\
\text { digunakan pada tiap } \\
\text { simulasi }\end{array}$ & $2,0 \times 10^{\prime}$ partikel \\
\hline $\begin{array}{l}\text { History dari phsp file } \\
\text { Rata-rata survival ratio }\end{array}$ & $8,456 \times 10^{\prime}$ partikel \\
\hline $\begin{array}{l}\text { Prediksi partikel yang } \\
\text { dibutuhkan }\end{array}$ & $1,460 \times 10^{9}$ partikel \\
\hline $\begin{array}{l}\text { Rata-rata Jumlah } \\
\text { partikel terblok MLC }\end{array}$ & $1,052 \times 10^{7}$ partikel \\
\hline $\begin{array}{l}\text { Rata-rata waktu } \\
\text { simulasi: }\end{array}$ & \\
\multicolumn{1}{c}{ Komputer i5 } & 1,204 jam \\
\hline Komputer i3 & 2,15 jam \\
\hline Rata-rata History/jam & $3,362 \times 10^{6}$ \\
\hline
\end{tabular}

jumlah history dari phsp file untuk setiap simulasi selalu bernilai sama walaupun simulasi dilakukan pada komputer berbeda. Hal ini diakibatkan karena seluruh simulasi dilakukan menggunakan phase spase file yang sama dan dengan pengaturan jumlah history partikel yang sama pula. Sedangkan nilai survival ratio, jumlah partikel yang terblok oleh MLC, waktu simulasi, dan jumlah history/ jam dari setiap simulasi memiliki nilai 
nilai yang berbeda. Nilai yang berbeda ini kemungkinan terjadi dikarenakan oleh mekanisme perhitungan metode Monte Carlo yang memanfaatkan bilangan random berbeda pada setiap simulasi yang dilakukan dan dipengaruhi pula oleh perbedaan spesifikasi komputer yang digunakan dalam simulasi, sehingga informasi dari survival ratio, jumlah partikel yang terblok oleh MLC, waktu simulasi, dan jumlah history/jam pada Tabel 2 hanya menyajikan nilai rataratanya saja. Selain itu dapat dihitung pula waktu total yang dibutuhkan untuk menyelesaikan seluruh simulasi VMAT, yakni sekitar 62,939 jam atau kurang lebih 2,6225 hari.

Simulasi VMAT dengan control point yang berbeda tentu saja akan menghasilkan distribusi dosis yang berbeda tentu saja akan menghasilkan distribusi dosis yang berbeda pula, karena distribusi dosis akan dipengaruhi oleh variabel yang berubah selama gantry berotasi, dalam hal ini yang paling utama adalah posisi sudut gantry saat dosis dihantarkan, dan bentuk berkas yang diatur oleh posisi MLC. Gambar 2 menampilkan distribusi dosis yang dinyatakan dalam kurva isodosis dua

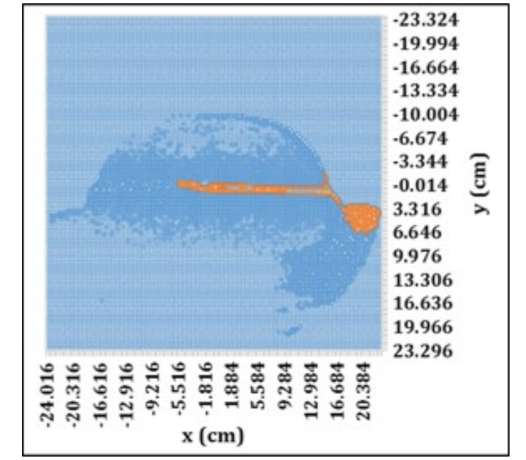

(a)

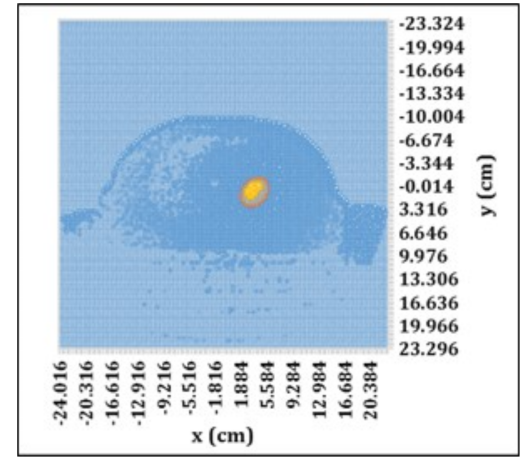

(b)

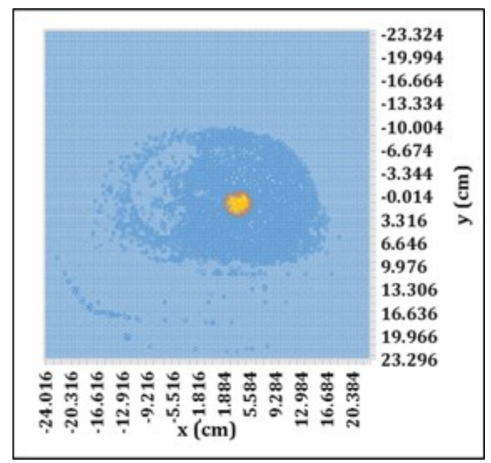

(c)

Gambar 2. Kurva isodosis pada slice 73 dari simulasi dengan menggunakan (a) control point VMAT 1-3 (b) control point VMAT 55-57 (c) control point VMAT 112-114 (sumber: data simulasi).

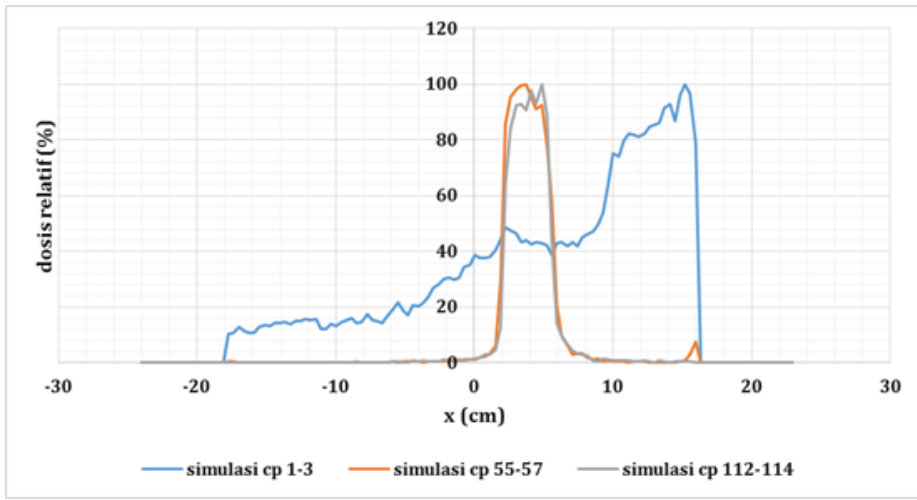

Gambar 3. Profil dosis pada slice 73 dari simulasi dengan penggunaan control point VMAT berbeda (sumber: data simulasi). 
dimensi dari beberapa simulasi VMAT MC dengan control point yang berbeda, serta Gambar 3 menampilkan hasil analisa nilai dosis pada profil 1D untuk slice 73 pada simulasi VMAT MC sepanjang sumbu $\mathrm{x}$.

Data nilai dosis pada setiap voxel yang terdapat pada file output .3ddose untuk seluruh simulasi selanjutnya diolah dan dianalisis dengan menggunakan beberapa metode statistika sederhana, dengan tujuan untuk mengetahui karakteristik kurva isodosis akhir yang terbentuk. Metode pengolahan tersebut antara lain adalah dengan menjumlahkan seluruh data dosis pada setiap voxel yang sama dari seluruh pengulangan simulasi dan

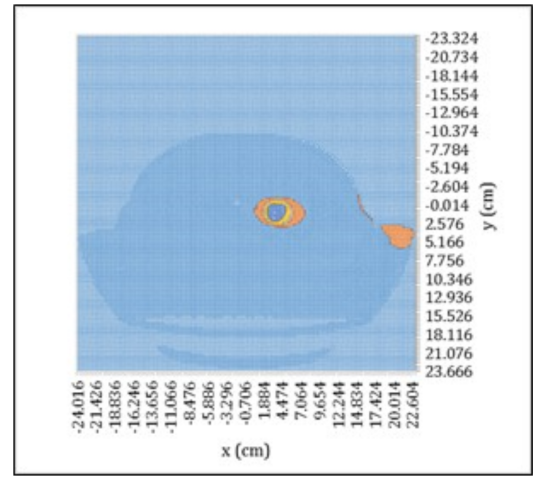

(a)

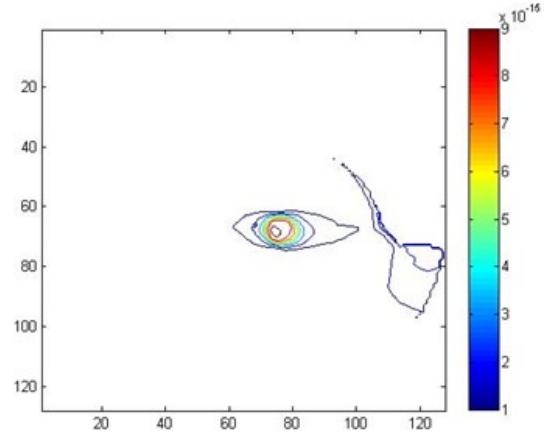

(c) merata-ratakan seluruh data dosis pada setiap voxel yang sama dari seluruh pengulangan simulasi. Kurva isodosis yang terbentuk hasil pengolahan data dengan beberapa metode pengolahan ditunjukkan Gambar 4.

Gambar 4. (a) dan (b) menunjukkan bentuk kurva isodosis yang menyatakan distribusi dosis VMAT dari hasil penjumlahan data dosis (dosis total) dan hasil rata-rata nilai data dosis memiliki bentuk dan pola yang sama persis, walaupun sebenarnya nilai dosis yang terdapat pada kedua kurva memiliki nilai yang berbeda. Sedangkan pada Gambar 4. (c) dan (d) sangat terlihat perbedaan yang signifikan antara distribusi dosis hasil

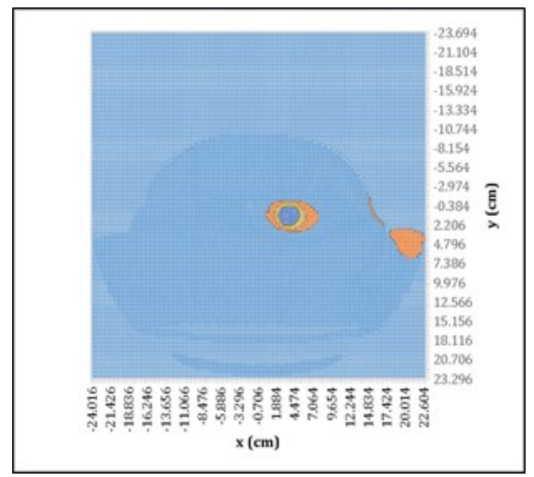

(b)

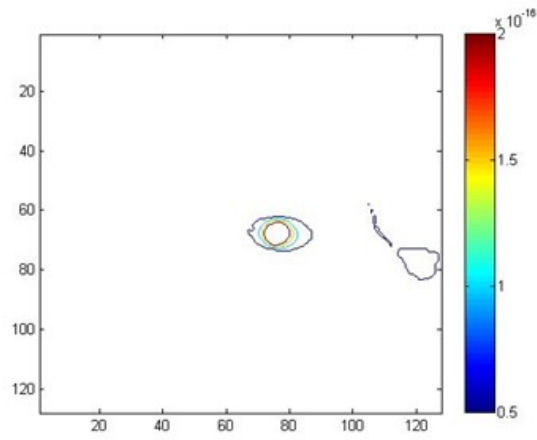

(d)

Gambar 4. Kurva isodosis VMAT pada slice ke 73 dari seluruh simulasi yang dibentuk hasil penjumlahan dosis (dosis total pada masing-masing voxel) dan hasil rata-rata dosis (dosis rata-rata pada masing-masing voxel). (a) dan (b) menggunakan program microsoft excel, (c) dan (d) menggunakan program matlab. (sumber: data simulasi) 
penjumlahan dan hasil rata-rata dosis, baik dari segi bentuk maupun dari segi warna. Untuk hasil penjumlahan dosis (dosis total) bentuk kurva isodosis yang terbentuk lebih lebar dibandingkan dengan hasil rata-rata dosis. Dapat terlihat pula bahwa kedua kurva sama-sama memiliki distribusi dosis yang terfokus pada daerah isocentre, artinya simulasi memberikan dosis tinggi pada daerah isocentre. Untuk analisis satu dimensi, grafik profil dosis yang terbentuk dari kurva isodosis hasil penjumlahan dosis dan rata-rata dosis dapat dilihat pada Gambar 5.

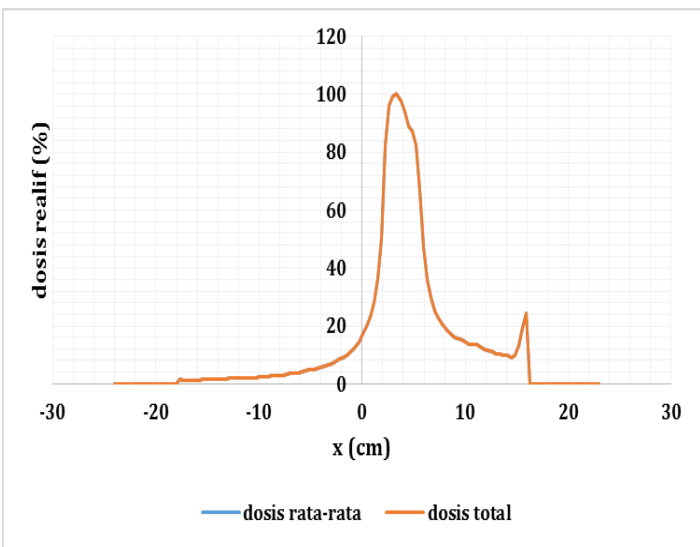

Gambar 5. Profil Dosis Hasil Penjumlahan (dosis total) dan Dosis Rata-rata dari dari seluruh simulasi pada titik isocentre. (sumber: data simulasi)

Walaupun jumlah total dosis dan ratarata dosis memiliki bentuk kurva isodosis dan profil dosis yang hampir serupa, namun pada kenyataannya kurva isodosis dan profil dosis pada tiap voxel phantom tersebut dibentuk dari nilai dosis yang sangat beragam. Hal ini dikarenakan simulasi dilakukan beberapa kali dengan menggunakan control point yang berbeda. Control point ini tentu saja diberikan untuk sudut gantry, bukaan MLC dan fraksi dosis yang berbeda sehingga akan menghantarkan dosis yang beragam pada tiap voxelnya.

Standar error dosis pada tiap voxel di daerah sekitar isosenter dari simulasi MC dengan membagi titik kontrol VMAT masih memiliki nilai yang sangat besar sebagaimana yang ditunjukkan Gambar 6 . Hal ini menunjukkan bahwa keragaman dosis yang terhantar pada tiap voxel phantom untuk setiap titik kontrol yang berbeda masih sangat besar terutama untuk di daerah penumbra yang dapat mencapai hingga ratusan persen. Untuk standar error dosis minimal di daerah sekitar isosenter adalah sekitar 24,31\%, sedangkan nilai standar error tepat di titik isosenter adalah sekitar 31,22\%.

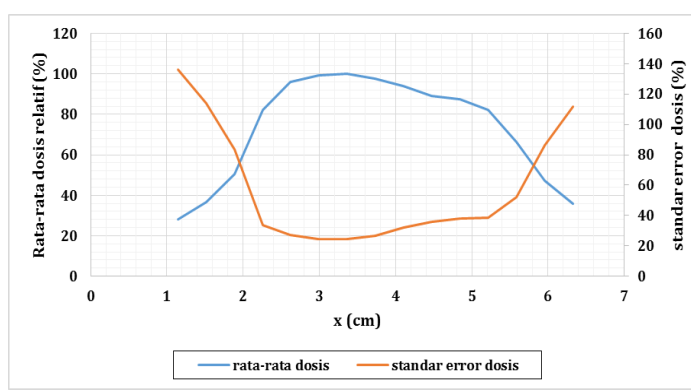

Gambar 6. Grafik Standar Error Dosis Daerah Sekitar Isosenter (sumber: data simulasi).

Sebagai perbandingan dalam penelitian ini dilakukan pula simulasi dengan menggunakan seluruh jumlah control point sekaligus (simulasi dilakukan sekali, tanpa adanya pembagian jumlah control 
point sekaligus (simulasi dilakukan sekali, tanpa adanya pembagian jumlah control point). Namun jumlah history partikel yang digunakan relatif sedikit jika dibandingkan dengan jumlah history partikel yang digunakan dalam simulasi berulang. Dalam simulasi ini jumlah history yang digunakan hanya $6 \times 10^{7}$ partikel. Tujuannya adalah untuk mengetahui karakteristik bentuk distribusi dosis 2D yang terbentuk dari kedua simulasi.

Gambar 7 adalah gambar perbandingan distribusi dosis VMAT berkas foton 6 MV pada slice 73 yang ditampilkan

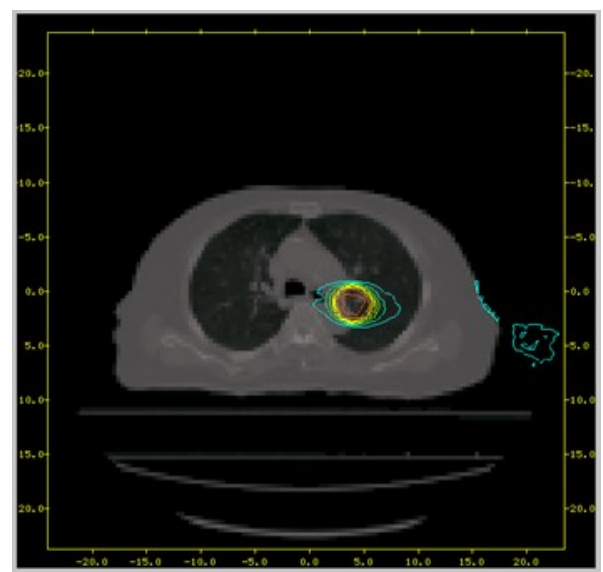

(a)

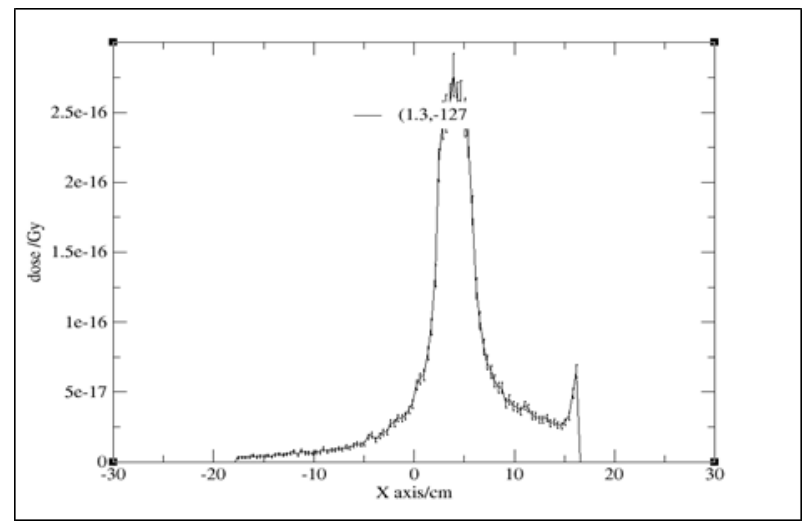

(c) dengan menggunakan program dosxyz_show (untuk hasil simulasi dengan menggunakan seluruh jumlah control point) dan program microsoft excel (untuk hasil simulasi dengan membagi jumlah jumlah control point). Tampak bahwa bentuk kurva isodosis dari simulasi yang dilakukan dengan membagi jumlah control point dan simulasi dengan menggunakan seluruh control point memiliki bentuk pola distribusi dosis yang hampir sama. Begitu pula dengan bentuk profil dosisnya. Namun tentu saja jika dilihat dari nilai dosis relatif yang terhantar pada tiap voxel akan memiliki

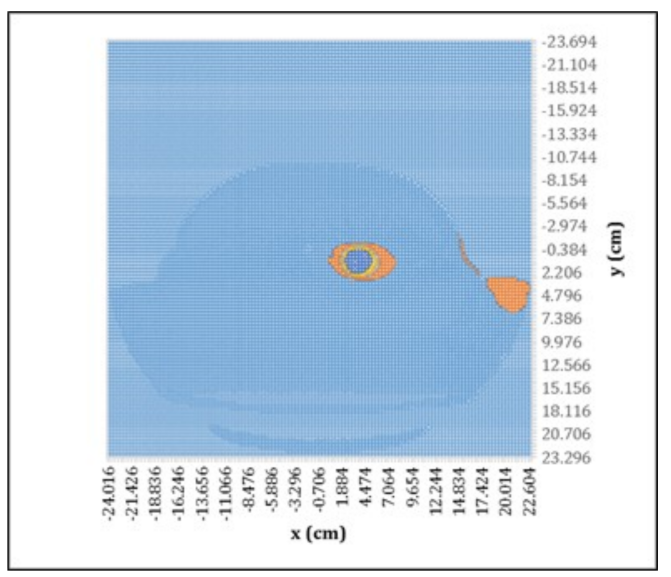

(b)

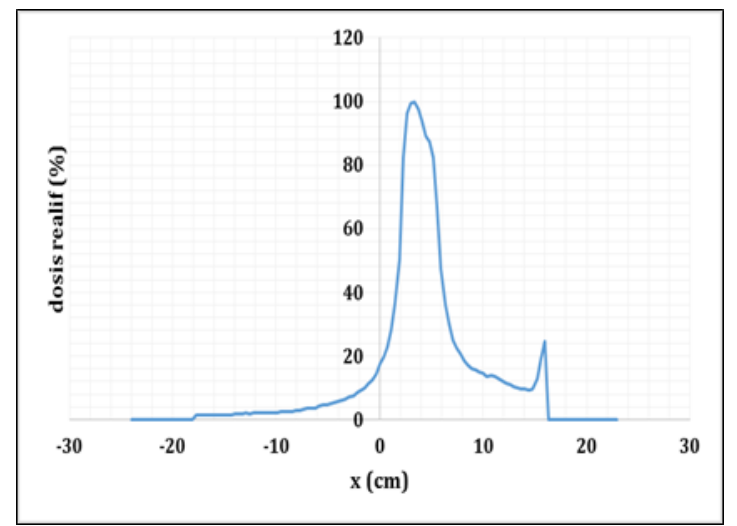

(d)

Gambar 7. Perbandingan Distribusi Dosis VMAT slice 73 untuk simulasi dengan menggunakan seluruh control point dan simulasi dengan pembagian control point (a) dan (b) kurva isodosis 2D (c) dan (d) profil Dosis 1D. (sumber: data simulasi) 
nilai dosis yang berbeda. Untuk simulasi dengan menggunakan seluruh control point dengan jumlah history sebanyak $6 \times 10^{7}$ partikel nilai maksimum dosisnya adalah sekitar $2,54 \times 10^{-16} \mathrm{cGy}$, dan untuk simulasi dengan membagi control point ke dalam beberapa kali pengulangan simulasi menggunakan jumlah total history 7,6 $\mathrm{x} \quad 10^{8}$ partikel nilai maksimum dosisnya adalah sekitar $2,46 \times 10^{-16}$ cGy. Nilai maksimum keduanya memiliki perbedaan yang tidak terlalu signifikan, namun untuk dapat menghasilkan bentuk kurva isodosis dan profil dosis dari kedua metode simulasi dengan nilai dosis yang sama persis belum dapat diketahui secara pasti.

\section{Simpulan}

Simulasi pembentukan kurva isodosis untuk teknik radioterapi VMAT telah berhasil dilakukan melalui penggunaan EGSnrc. Simulasi VMAT yang dilakukan dengan membagi control point ke dalam beberapa kali simulasi memiliki pola kurva isodosis yang hampir menyerupai dengan kurva isodosis hasil simulasi VMAT dengan menggunakan seluruh control point sekaligus. Namun, perbandingan jumlah history partikel yang digunakan untuk membentuk kurva isodosis yang sama persis antara kedua simulasi belum dapat diketahui secara pasti. Pengkajian lebih lanjut mengenai simulasi dengan membagi jumlah control point masih harus dilakukan untuk dapat dijadikan salah satu solusi dalam mengatasi keterbatasan spesifikasi komputer yang tersedia dalam melakukan simulasi Monte Carlo dalam rangka melakukan perncanaan pengobatan radiasi yang tepat.

\section{Ucapan Terima Kasih}

Penulis mengucapkan terima kasih kepada Lab. Fisika Nuklir dan Biofisika, serta Lab. Komputasi ITB, atas perizinan menggunakan fasilitas komputer dalam penelitian ini. Selain itu penulis juga mengucapkan terimakasih kepada Politeknik Al Islam Bandung yang telah mendanai penelitian ini melalui Penelitian Dosen Pemula 2017.

\section{Referensi}

1. Omer, HB., Salim, EH., Elhag, B.,dan Sulaeman, A. (2012). Monte Carlo Technique in Radiation Medicine, Review Article, Asian J Med Cli Sci, Vol.1, 35-39.

2. Chetty, I.J., Curran, B., Cygler, J., DeMarco, J.J., Ezzell, G., Faddegon, B.A., Kawrakow, I., Keall, P.J., Liu, H., Ma, C.M., 
(2007). Report of the AAPM Task Group No. 105: Issues associated with clinical implementation of Monte Carlo-based photon and electron external beam treatment planning, Medical Physics,34, No. 12, 4818-4851.

3. Kawrakow, I., Mainegra-Hing, E., Roger, D., Tessier, F., dan Walters, B. (2013). The EGSnrc Code System: Monte Carlo Simulation of Electron and Photon Transport, National Research Council of Canada, Ottawa, Report PIRS-701.

4. Tsai C-L., Wu J-K., Chao H-L., Tsai Y-C., dan Cheng J. C-H. (2011). Treatment and Dosimetric Advantages between VMAT, IMRT, and Helical Tomotherapy in Prostate Cancer, Medical Dosimetry, 36, 264271.

5. Hardcastel, N., Tome, W.A., Foo, K., Miller, F.A., Carolan, M., dan Metcalfe, P. (2011). Comparison of Prostate IMRT and VMAT Biologically Optimised Treatment Plans. Medical Dosimetry, 36, 292298.

6. Boylan, C. J., Golby, C., and Rowbottom, C. G. (2010). A VMAT planning Solution for Prostate Patiens Using a Commersial Treatment Planning System. Physics in Medicine and Biology.55, 395404.

7. American Lung Assosiation. (2010). State of Lung Lung Disease in Diverse Communities. American Lung Association National Headquarters, Pennsylvania, Avenue, 55-62.
8. Arvidson, Pader. (2011). Implementation and Evaluation of Volumetric Modulated Arc Therapy at the Radiation Therapy, Master thesis in medical radiation physics, Departement at The University Hospital of Umea. Sweden.

9. Lobo, J. dan Popescu, A. (2010). Two new DOSXYZnrc sources for 4D Monte Carlo simulations of continuously variable beam configurations, with applications to RapidArc, VMAT, TomoTherapy and CyberKnife,Phys. Med. Biol,55, 4431-4443.

10. Palma, D., Vollans, E., James, K., Nakano, R., Moiseenko, V., Shaffer, R., McKenzie, M., Morris, J., dan Otto, K. (2008). Volumetric Modulated Arc Therapy for Delivery of Prostate Radiotherapy: Comparison with Intensity Modulated Radiotherapy and ThreeDimensional Conformal radiotherapy, Radiation Oncology Biol. Phys., Vol. 72, No. 4, 9961001.

11. Roger, D., Kawrakow, I., dan Walters, B. (2013). BEAMnrc Users Manual. National Research Council of Canada, Ottawa, Report PIRS-509.

12. Walters, B., Kawrakow, I,. dan Roger, D. (2013). DOSXYZnrc User Manual. National Research Council of Canada, Ottawa, Report PIRS-794. 